\title{
Dampak Game Online Mobile Legends: Bang Bang terhadap Mahasiswa
}

\section{Impact of Online Mobile Legends Game: Bang Bang for Students}

\author{
Devita Rani*, Effiati Juliana Hasibuan \& Rehia K. Isabela Barus \\ Program Studi Ilmu Komunikasi, Fakultas Ilmu Sosial dan Ilmu Politik \\ Universitas Medan Area, Indonesia
}

Diterima: Mei 2019; Disetujui: Mei 2019; Dipublish: Juni 2019

\begin{abstract}
Abstrak
Game Online Mobile Legends: Bang Bang merupakan salah satu wujud dari perkembangan teknologi dalam media baru. Tujuan penelitian ini adalah untuk mengetahui bagaimanakah dampak positif dan dampak negatif dari bermain game online Mobile Legends: Bang Bang terhadap mahasiswa di Fakultas Ilmu Sosial dan Ilmu Politik Universitas Medan Area yang bermain game. Teori yang dipakai dalam penelitian ini antara lain komunikasi, new media, dampak positif dan negatif game online. Metode yang digunakan adalah metode kualitatif. Dimana yang menjadi informan dalam penelitian ini kelima mahasiswa di Fakultas Ilmu Sosial dan Ilmu Politik Universitas Medan Area.Teknik pengumpulan data dilakukan dengan cara observasi partisipasi, wawancara mendalam serta bukti dokumentasi. Hasil penelitian menunjukkan bahwa dampak dari bermain Mobile Legends dipengaruhi bagaimana sikap dari para pemainnya, acuh terhadap lingkungan sosialnya, boros dalam segi waktu dan ekonomi, bisa mendapatkan teman baru di dunia maya dari negara lain sehingga tidak membatasi hubungan interaksi, menambah wawasan dan pengalaman mengenai teknologi.
\end{abstract}

Kata Kunci: Komunikasi, New Media, Dampak Positif dan Negatif Game Online.

\begin{abstract}
Mobile Legends Online Games: Bang Bang is one manifestation of technological development in new media. The purpose of this study was to find out how the positive and negative impact of playing Mobile Legends: Bang Bang online games to FISIP UMA students who play games. The theory used in this study is communication, new media, positive and negative online games. The method used is a qualitative method. Where the informants fifth in FISIP UMA students. Data collection techniques are carried out by means of participatory observation, in-depth interviews and documentary evidence. The result of the study show that the impact of playing Mobile Legends is influenced by the attitude of the players, indifferent to the social environment, wasteful in terms of time and economy, can get new friends in cyberspace from other countries so as not to limit interaction, add insight and experience about technology.
\end{abstract}

Keywords: Communication, New Media, Positive Impact and Negative Online Games.

How to Cite: Rani, D. Hasibuan, E.J. \& Barus, R.K.I. (2018). Dampak Game Online Mobile Legends: Bang Bang terhadap Mahasiswa. PERSPEKTIF, 7 (1): 6-12.

${ }^{*}$ Corresponding author:

ISSN 2085-0328 (Print)

E-mail: : devita.rani12@gmail.com 


\section{PENDAHULUAN}

Game Mobile Legends: Bang Bang (MLBB) merupakan salah satu game online yang merupakan wujud dari perkembangan teknologi elektronik yang semakin hari semakin pesat pada era globalisasi saat ini. Bermain game online dapat dilakukan di layar monitor komputer atau layar telepon seluler, yang semula telepon seluler hanya digunakan untuk memenuhi kebutuhan komunikasi, sekarang juga bisa digunakan untuk melakukan banyak hal termasuk bermain game online ataupun game offline. Game terbagi atas dua jenis, pertama adalah game offline yang bisa kita mainkan pada perangkat komputer atau telepon selulertanpa harus terhubung ke jaringan internet. Kedua adalah game online yang hanya bisa kita mainkan komputer atau telepon selulersaat terhubung dengan jaringan internet.

$M L B B$ adalah game multiplayer online batlle arena (MOBA) yang mirip dengan game Dota 2 dimana game ini menggunakan strategi untuk menang, dengan pertarungan 5 versus 5 melawan tim musuh. Game ini mempunyai 3 jalur (line) yang diperkuat dengan tower tujuannya sama yaitu untuk menghancurkan tower utama musuh dengan hero yang kita gunakan. Game online MLBB saat ini sedang marak (booming) di masyarakat, peminatnya tidak pandang bulu mulai dari anak-anak sampai orang dewasa termasuk mahasiswa.

Game online sudah masuk dari waktu yang cukup lama di Indonesia, penyebarannya pun sangat cepat sekali terutama dalam waktu empat tahun terakhir sudah diminati kurang lebih 50 juta peminat game yang sudah mengunduh aplikasi game online $M L B B$ ini. Game yang satu ini memang menjadi sangat populer belakangan ini. Sebelumnya juga ada satu game online bernama Clash of Clans (COC) yang sangat populer. Tetapi seiring berjalannya waktu tadi, game Clash of Clans mulai ditinggalkan dan sekarang banyak dari kalangan mahasiswa beralih ke game online $M L B B$. Game online merupakan aplikasi permainan yang terdiri dari beberapa game yang memiliki aturan main dan tingkatantingkatan tertentu.

Bermain game online adalah suatu kegiatan yang dilakukan dengan tujuan untuk memperoleh kesenangan tanpa mempertimbangkan apa yang akan terjadi dari kegiatan tesebut. Bermain game memberikan rasa penasaran dan kepuasan psikologis pada diri sehingga membuat pemain semakin tertarik dalam memainkannya. Kepuasaan psikologis yang dimaksud berakibat membuat seseorang yang bermain game menjadi kecanduan sehingga melupakan kegiatan aktivitas di luar dari game. Bermain game online seolah menjadi gaya hidup tersendiri dan banyak digemari kalangan segala usia karena bisa memberi bentuk rasa kepuasan dan hiburan di waktu luang.

Saat ini yang cukup popular dikalangan remaja akhir atau mahasiswa pengguna telepon seluler adalah Game MLBB. Fenomena game $M L B B$ ini sudah tidak asing lagi dan sudah menjadi virus yang menjalar ke seluruh dunia.Game MLBB berjenis strategis ini sangat menarik sehingga membuat para pemainnya menjadi ambisius dalam bermain. $M L B B$ itu sendiri adalah game yang bergenre multiplayer online battle arena (MOBA) yang bertujuan menghancurkan tower milik tim lawan untuk mencapai kemenangan, perusahaan yang menggembangkan game ini adalah sebuah perusahaan yang berasal dari kota China yang bernama Moonton. Game $M L B B$ sebenarnya baik untuk ajang hiburan seseorang dan baik dalam hal melatih ketangkasan dalam bermain, tetapi disarankan kepada orang yang bermain game harus dapat mengontrol dirinya sendiri, sehingga tidak berakibat kecanduan yang berlebihan.

Mahasiswa FISIP UMA juga tidak bisa terlepas dari telepon selulernya, baik itu di kampus, di kantin kampus, ataupun di luar dari kampus diakibatkan bermain game online $M L B B$ tersebut. Mereka kerap menghabiskan waktunya berjam-jam hanya untuk bermain game online, alasan kenapa mengambil mahasiswa di FISIP UMA sebagai responden karena, banyaknya game center ataupun mahasiswa yang bersedia membagi sambungan koneksi internet kepada mahasiswa lainnya di kampus hanya untuk main bareng game online bersama-sama dan membentuk sebuah tim di dalam permainan tersebut.

\section{METODE PENELITIAN}

Metode pengkajian yang digunakan dalam penelitian ini adalah pendekatan kualitatif. Penelitian kualitatif dengan metode 
penelitian deskriptif kualitatif. Maka untuk memudahkan penjelasan mengenai Dampak Game Online Mobile Legends: Bang Bang Terhadap Mahasiswa di Fakultas Ilmu Sosial dan Ilmu Politik, maka dapat dilihat dari dua aspek yaitu: 1) Dampak positif bermain game $M L B B$; 2) Dampak negatif bermain game $M L B B$

Kategorisasi sumber data dalam penelitian kualitatif yaitu: Mahasiswa di Fakultas Ilmu Sosial dan Ilmu Politik Universitas Medan Area yang sudah bermain game online $M L B B$ selama setahun, informan yang di dapat adalah gamers terdiri dari lima orang yang bernama Novi, Irin, Lian, Arie dan Aan.

Peneliti melakukan penelitian yang bersumber dari data primer yaitu observasi partisipasi, wawancara mendalam dan dokumentasi yang dilakukan di Fakultas Ilmu Sosial dan Ilmu Politik Universitas Medan Area. Instrumen penelitian yang digunakan dalam penelitian ini yaitu melihat dari segi observasi partisipasi meliputi pengamatan dan pengalaman selama menjadi gamers. Melihat dari segi wawancara mendalam, instrumen penelitian meliputi rekaman wawancara yang menggunakan telepon seluler sebagai alat perekam suara. Melihat dari segi dokumentasi berupa foto, telepon seluler dan laptop.

Teknik pengumpulan data lebih banyak pada observasi partisipasi berperan serta, wawancara mendalam, dan dokumentasi. Teknik analisis yang digunakan adalah reduksi data, penyajian data, penarik kesimpulan dan verifikasi. Keabsahan data yang digunakan yaitu perpanjang pengamatan, meningkatkan kecermatan dalam penelitian, triangulasi, menggunakan bahan refrensi, dan mengadakan membercheck.

\section{HASIL DAN PEMBAHASAN}

Hasil penelitian ini diperoleh dengan cara teknik wawancara secara mendalam dengan informan sebagai bentuk pencarian data dan dokumentasi langsung dari lapangan yang kemudian peneliti analisis. Fokus analisis penelitian ini adalah pengguna telepon seluler yang bermain game online Mobile Legends: Bang Bang selama setahun yaitu Mahasiswa Fisip UMA terkait dengan judul skrispi peneliti "Dampak Game Online Mobile Legends: Bang Bang terhadap Mahasiswa di Fakultas Ilmu Sosial dan Ilmu Politik Universitas Medan Area". Data yang diperoleh selama penelitian akan disajikan dengan metode kualitatif, kemudian data dianalisis dengan teknik deskriptif. Data yang disampaikan berdasarkan jawaban informan.

Dampak Game Online MLBB terhadap Mahasiswadi Fakultas Ilmu Sosial dan Ilmu Politik Universitas Medan Area merupakan salah satu contoh dari banyaknya teknologi yang kian lama semakin canggih sehingga game online sendiri dimainkan dengan menggunakan teknologi jaringan internet (media online). Media online adalah media baru yang saat ini menjadi salah satu kebutuhan manusia yang sangat wajib, karena tidak hanya untuk bermain game online saja (sebagai hiburan) yang menjadi kebutuhan tetapi kebutuhan dalam hal berbisnis juga menggunakan media online tadi (misalnya berbisnis di Instagram, Facebook, Whatsapp, dan aplikasi media baru lainnya) cara menggunakannya harus terhubung dengan jaringan internet karena kalau tidak ada jaringan internet maka tidak dapat berfunsi dengan baik, jadi media baru ini dapat dikatakan sebagai komunikasi baru dalam bidang media baru tersebut.

Dalam penelitian ini peneliti melakukan pengamatan (observasi partisipasi) bagaimana proses interaksi yang terjadi kepada narasumber dan mengamati bagaimana tuntutan di dalam bermain game tersebut, yaitu sebagai berikut: Pertama. Para pemain game yaitu mahasiswa Fakultas Ilmu Sosial dan Ilmu Politik Universitas Medan Area sebagai narasumber peneliti, mereka melakukan proses interaksi pada saat bermain game dengan cara mencari posisi duduk mereka cenderung lebih mencari tempat yang nyaman dan jauh dari gangguan orang lain atau bahkan berkumpul disatu tempat untuk bermain sama dengan temantemannya, ketangkasan tangan para pemain game akan lebih cepat dalam mengusap atau menekan tombol layar telepon seluler ketika sedang bermain game dan mata mereka saat bermain game fokus ke layar telepon selulernya jika ada teman yang mengajak berbicara maka mereka tetap akan fokus ke layar telepon seluler sambil berbicara dengan temannya tanpa melihat balik mata sang teman (tidak menatap lawan bicaranya) sehingga dapat dikatakan bahwa mereka sudah acuh terhadap lingkungan sekitarnya. 
Kedua, Menurut peneliti para pemain game online $M L B B$ inimembutuhkan tuntutan konsentrasi penuh terhadap game, karena game online $M L B B$ ini adalah game yang menggambarkan situasi perang jadi ketika kita bermain akan serasa kita yang sedang ada di dalam game tersebut untuk mengalahkan lawan, bahkan ketika lagi seru-serunya atau dapat dikatakan kita menang berturut-turut dalam bermain, kita akan terus-menerus tertarik untuk bermain lagi dengan teman satu tim kita agar sama-sama mencapai tujuan dan naik peringkat dalam game $M L B B$ sehingga dapat dikatakan bahwa bermain game tersebut akan berakibat buruk bagi para pemainnya yang akan berakibat pada kecanduan. Selain itu, di dalam game $M L B B$ para pemainnya harus mengikuti praturanperaturan yang telah ditetapkan jadi jika ada yang tidak ikut aturan main maka akan dikenakan pelanggaran berupa sanksi dengan tujuan mendapatkan hak adil (tidak membedabedakan setiap pemain dalam game).

Menurut Rudiyansah (2014) Adapun dampak dari bermain game online yaitu: 1) Dampak positif game online: Game Online dapat berfungsi sebagai wadah bersosialisasi dengan pemain lain bahkan dengan pemain yang berasal dari berbagai negara, game online dapat melatih kita untuk bekerja sama dengan team yang cara bermainnya menyusun strategi kelompok pada tim tersebut contohnya seperti game pointblank dan DOTA 68, dapat menghilangkan stress dan dapat melatih koordinasi antara mata dan tangan serta skill motorik. Game online dapat menghubungkan kita dengan pemain lain di seluruh dunia sehingga kita dapat bertegur sapa dan bersosialisasi dengan mereka.

2) Dampak negatif game online: Perilaku negatif yang diperoleh dari hasil penelitian memperlihatkan bahwa hampir semua berdampak pada sikap yang kemudian hal ini tercermin pada perilaku gamers yang mengadopsi permainan online tersebut. Adapun beberapa perilaku yang timbul akan dijelaskan sebagai tidak kenal waktu atau lupa waktu, kebanyakan dari gamersyang bermain game online membuat sering lupa waktu untuk rutinitas dan menimbulkan efek ketagihan yang berakibat melalaikan kehidupan dan kegiatan lainnya, sosialisasi dengan teman jadi berkurang, pikiran kita jadi terus menerus memikirkan game yang dimainkan sehingga membuat kita jadi cuek, acuh tak acuh, kurang peduli terhadap hal-hal yang terjadi di sekeliling kita.

Adapun hasil penelitian yang peneliti teliti dari narasumber bahwa game online itu sendiri bisa berakibat kecanduan jika dimainkan secara terus-menerus terlihat dari keasyikan para mahasiswa Fakultas Ilmu Sosial dan Ilmu Politik Universitas Medan Area yang bermain game karena ketika bermain bisa barengan dengan teman pasti akan menjadi kepuasan sendiri apalagi timnya pro (bagus dalam bermain) bahkan kita dapat berinteraksi dengan pemain dari negara lain seperti mendapatkan teman baru dengan hobbi yang sama yaitu bermain game. Game Online $M L B B$ dijadikan sebagai pelarian bagi mahasiswa di waktu senggang atau sedang stress, game tersebut merupakan salah satu sarana media hiburan yang sampai saat ini booming dikalangan pelajar maupun mahasiswa yang memainkannya. Fenomena tersebut yang menjadikan mahasiswa itu bermain game salah satunya tadi adalah tidak adanya aktifitas lain atau memang hanya untuk menghibur dirinya dengan cara mengisi waktu luang bermain game online. Sehingga bisa dikatakan pemain game tersebut sudah masuk ke dalam dunia maya (Virtual World) yang cara bermainnya menggunakan imajinasi dan kreatifitas para pemainnya.

Dampak negatif dari bermain game online menurut Christianti 2006 (dikutip dalam Hilmuniati, 2011), membuat orang menjadi menjauh dengan lingkungan sekitar ini karena efek terlalu seringnya bermain game sehingga lupa dengan hubungan sosial dalam kehidupannya.

Berdasarkan pernyataan di atas bahwa dari hasil penelitian saya membenarkan bahwa pada saat bermain game dapat melupakan hubungan sosial kebanyakan narasumber yang peneliti teliti yaitu mahasiswa Fakultas Ilmu Sosial dan Ilmu Politik Universitas Medan Area menyatakan bahwa dengan bermain game online $M L B B$ justru dapat menambah hubungan sosial dan interaksi dengan orang banyak terutama dari negara lain, dimana menambah banyak teman tadi secara online.

Di satu sisi bermain $M L B B$ ini memang harus fokus karena kalau tidak fokus maka bermainnya pun akan tidak bagus, terlalu fokus dengan game pun bisa mengakibatkan 
acuh dengan lingkungan sekitarnya yang parahnya dari game online ini bisa berakibat kecanduan seperti salah satu narasumber saya yang bernama Lian, ia mengatakan ketika lagi beruntungnya ia bisa bermain game $M L B B$ ini selama 10 jam lamanya.

Ini terbukti dari hasil penelitian menurut Suryanto (2015) dampak negatif dari bermain game online adalah seseorang yang kecanduan game online menunjukan perilaku adiktif, para pemain game online tidak ingat waktu dalam bermain terkadang seseorang yang bermain game bisa bermain selama 12 jam lebih hanya demi bermain permainan online tersebut yang akhirnya menyebabkan kecanduan (adiktif) terhadap penggunanya.

Tetapi ada yang menyatakan salah satu narasumber saya yang bernama Novi bahwa dengan bermain game online bisa fokus artinya setelah kita masuk ke dalam game, setelah kita bertempur kita akan merasa bahwa kita ada di dalam game untuk mencapai tujuan tadi kita tidak bisalah berinteraksi karena tujuan kitakan meraih kemenangan, jadi kita harus benar-benar bermain karena tidak bisa memberhentikan game dikarenakan online jadi memang harus selesaikan dulu barulah kita bisa berinteraksi.

Warih dan Linaldi (2016) adanya motivasigamers sehingga terjadinya kecanduan pada saat bermain online game. 1) Komponen pencapaian: a) Kenaikan: Keinginan untuk mendapatkan kekuatan, kecepatan perubahan, dan akumulasi dalam kekayaan atau status karakter di game tersebut; b) Mekanis: Memiliki keinginan untuk menganalisis aturan dan sistem game untuk mengoptimalkan kemampuan karakter game; c) Kompetisi: Keinginan untuk menantang dan berkompetisi dengan gamers lainnya.

2. Komponen sosial: a). Sosialisasi: Memiliki keinginan untuk membantu dan bercakap-cakap (chat) dengan gamers lain, b) Hubungan: Keinginan untuk membentuk hubungan pertemanan dengan jangka waktu lama dengan yang lain, c) Kerjasama: Mendapatkan kepuasan menjadi bagian dari usaha kelompok permainan. 3. Komponen terjun mendalam di dunia game: a) Penemuan: Mencari dan mengetahu sesuatu terlebih dahulu yang kebanyakan gamers lain tidak mengetauinya; b) Peran: Menciptakan suatu karakter dengan latar belakangnya dan berinteraksi dengan gamers lain untuk menambah cerita baru; c) Modifikasi: Mempunyai ketertarikan dalam modifikasi karakter mereka.

Berdasarkan motivasi di atas peneliti membenarkan bahwa seseorang yang bermain game online mempunyai keinginan untuk menang dari pemain lain seperti dari hasil peneliti yang diteliti yaitu narasumber mahasiswa di FISIP UMA menyatakan bahwa keinginan untuk memang itu adalah kepuasan sendiri bagi para pemainnya seperti tujuan yang dituju itu sudah tercapai, bisa membentuk hubungan interaksi dengan para pemain lain baik dari satu negara ataupun beda negara, bisa melakukan komunikasi dengan para pemain game yang sama, mempunyai kreatifitas mengatur strategi jalannya tujuan dari satu tim untuk mengalahkan tim lawan, menambah wawasan dalam pengalaman mencari tahu sesuatu hal yang berhungan dengan game yang tidak diketahui oleh si pemain game tersebut.

\section{SIMPULAN}

Dampak positif dari bermain game online $M L B B$ terhadap mahasiswa di Fakultas Ilmu Sosial dan Ilmu Politik Universitas Medan Area secara positif sangat bermanfaat sehingga mahasiswa yang bosan dapat meluangkan waktu senggangnya dengan cara bermain game (kebutuhan sarana hiburan) bagi diri pribadi orang tersebut terpenuhi, salah satu narasumber peneliti yang dapat membedakan mana kehidupan nyata dengan mana yang bermain game (tidak terlalu menjadikan game itu sebagai sesuatu yang wajib), melatih berkomunikasi dengan baik, dapat menambah kawan secara online, adanya manfaat teknologi dalam bermain game sangat membantu seperti dapat melatih kita membaca dengan teliti. Karena para narasumber dapat pengetahuan dan pembelajaran cara bermain game lewat teknologi media online tadi, belajar mengetahui cara mainnya lewat video di channel youtobe jadi bisa memotivasi kita atau orang lain dalam melakukan permainan.

Dampak negatifnya membuang-buang waktu dan ekonomi secara percuma,menjadi kecanduan dalam hal ketika bermain tidak ingat waktu karena bermain secara berlebihan terus-menerus bahkan bisa juga ketika main game tidak peduli dengan 
hubungan interaksi dan sosial (acuh) dengan orang sekitarnya, adapun perasaan dalam mengungkapkan kekecewaan ketika kalah masing-masing punya gaya mengekspresikannya sendiri misalnya bisa berkata kasar, menjatuhkan lawan atau kawan, ada pula yang melupakan waktu sehingga melalaikan kehidupan nyatanya contohnya dalam hal ibadah, nasihat orang tua, berinteraksi dengan teman dari dunia nyata, selain itu juga ada beberapa narasumber yang menyatakan bahwa gangguan tidurnya jauh lebih lama dibandingkan orang yang tidak bermain game online tersebut.

\section{DAFTAR PUSTAKA}

Ahmadi, A. \& Sholeh, M. (2005). Psikologi Perkembangan. Jakarta: Rineka Cipta.

Arikunto, S. (2010). Prosedur Penelitian Suatu Pendekatan Praktik. Yogyakarta: Rineka Cipta.

Cangara, H. (1998). Pengantar Ilmu Komunikasi. Jakarta: PT Raja Grafindo Persada.

Effendy, O.U. (2009). Ilmu Komunikasi Teori dan Praktek. Bandung: PT Remaja Rosdakarya.

Holmes, D. (2005). Communication Theory: Media, Technology, and Society. London: Sage Publications.

Hurlock, E.B. (1994). Psikologi Perkembangan: Suatu Pendekatan Sepanjang Rentang Kehidupan. Jakarta: Erlangga.

Kriyantono, R. (2006). Teknik Praktis Riset Komunikasi. Jakarta: Kencana.

Kriyantono, R. (2010).Teknik Praktis Riset Komunikasi. Jakarta: Kencana.

Moleong, L. (2014). Metodelogi Penelitian Kualitatif Edisi Revisi. Bandung: PT. Remaja Rosda Karya.

Mondry (2008). Pemahaman Teori dan Praktik Jurnalistik. Bogor: Ghalia Indonesia.

Morrisan. (2013). Teori Komunikasi: Individu Hingga Massa. Jakarta: Kencana.

Sugiyono. (2015). Memahami Penelitian Kualitatif. Bandung: Alfabeta.

Sugiyono. (2006). Memahami Penelitian Kualitatif. Bandung: Alfabeta.

Sugiyono. (2007). Metode Penelitian Kuantitatif Kualitatif dan $R$ \& D. Bandung: Alfabeta.

Sugiyono. (2012). Metode Penelitian Kuantitatif Kualitatif dan $R \&$ D. Bandung: Alfabeta

Sugiyono. (2014). Memahami Penelitian Kualitatif. Bandung: Alfabeta

Gede, E.R. Hermawan, A. \& Achmad, S. (2009). Makalah Intranet/Internet Game Online. Yogyakarta: Fakultas Teknologi Industri UPN Veteran.
Haditono, S.R. dkk. (2006). Psikologi Perkembangan Pengantar dalam Berbagai Bagiannya. Edisi ke-16. Yogyakarta: Gadjah Mada University.

Hall, C.S. \& Lindzey, G. (1993). Psikologi Kepribadian 1 Teori-teo Psikodinamik (klinis). Yogyakarta: Kanisius.

Harsono, M. (2014). Pengaruh Bermain Game Terhadap Perkembangan Remaja. Surya University.

Hilmuniati, F. (2011). Dampak Bermain Game Online Dalam Pengamalan Ibadah Shalat Pada Anak di Kelurahan Pisangan Kecamatan Ciputat kota Tangerang Selatan. Jakarta: UIN Syarif Hidayatullah.

Jenab \& Ageng, H. (2015). Pengaruh Adiktif Game Online terhadap Prestasi Belajar Siswa Kelas $x$ SMAN 1 Cileungsi. Jakarta: Universitas Indraprasta PGRI. Journal of Education Volume 2 No.1.

Jumansyah, R. (2017). Fenomena Kecanduan game Online Pada Mahasiswa UMBY. Yogyakarta: Universitas Mercu Buana.

Dovey, L.M.J. Giddings, S. Grant, l. \& Kelly, K. (2009). New Media: A Critical Introduction (2 ed.). USA and Canada: Routledge.

Martha, A. (2017). Pengaruh Mobile Legends terhadap Manajemen Waktu Mahasiswa dalam Scribd, 26 Desember 2017.

Nasution. (2003). Metode Research. Jakarta: PT. Bumi Aksara.

Pawito, \& Sardjono, C. (1994). Teori-Teori Komunikasi. Buku pegangan Kuliah Fisipol komunikasi Massa S1 Semester IV. Surakarta: Universitas Sebelas Maret.

Rudiyansah. (2014). Dampak Game online terhadap Pelajar dan Mahasiswa (Studi kasus game center di Btp Kelurahan Tamalanrea). Makassar: Universitas Hasanuddin.

Silalahi. (2009). Metode Penelitian Sosial. Bandung: PT. Refika Aditama.

Siswoyo, D. (2007). Ilmu Pendidikan. Yogyakarta: UNY Press.

Santoso, S. (2002). Pendidikan Anak Usia Dini. Yogyakarta: FIP UNY.

Suryanto, R.N. (2015). Dampak Positif dan Negatif Permainan Game Online Dikalangan Pelajar. Pekanbaru: Univeristas Riau (Bina Widya). Jom Fisip Volume 2 No.2.

Syahran, R. (2015). Ketergantungan Online Game dan Penanganannya. Kota Palu Sulawesi Tengah: FKIP Universitas Tadulako. Journal Psikologi Pendidikan dan Konseling Volume 1 No.1 Juni.

Uma, D.M.C. (2014). Media Sosial dan Perkembangan Fashion Hijab Surakarta: Universitas Sebelas Maret.

Warih, A.P. \& Ananta, L. (2016). Hubungan antara Kecanduan Online Game dengan Depresi. 
Devita Rani, Effiati Juliana Hasibuan, Rehia K.Isabela Barus, Dampak Game Online Mobile

Yogyakarta: Universitas Muhammadiyah. Journal Mutiara Medika Vol. 9 No. 1:50-56, Januari 2009.

Weinstein, A.M. (2010). Computer and video game addiction: a comparison between game users and non-game users. The amirican journal of drug and alcohol abuse, 36:268-276, 2010. Doi:10.3109/00952990.2010.291879.

Wijiarti, D.N. (2016). Dampak Game Online Terhadap Pembelajaran Bahasa inggris (ditinjau dari persepsi mahasiswa). Manado: Universitas Sam Ratulangi.

Sumber website: Mobile Legends.com 